\title{
THE DISTRIBUTION OF REVENUES FROM STATE-COLLECTED CONSUMER TAXES
}

\author{
L.EDwin SMarT* and John N.Hart
}

The development of consumer taxes on a large scale is, so far as state and local governments are concerned, a comparatively recent phenomenon. Universal as was the motor fuel tax by I929, it was not until the early nineteen-thirties that taxes of this character were turned to as an important source of revenue. The extent of their development can best be grasped by a study of Table I.

\section{TABLE I}

State Tax Collections, Selected Years, I925-r940

(In millions of dollars)

\begin{tabular}{|c|c|c|c|c|c|c|c|}
\hline & & & & & & & \\
\hline & & SOURCES & SALES TAX & DLLECTIONS & & & $\begin{array}{l}\text { Per Cent of } \\
\text { Grand Total of }\end{array}$ \\
\hline Year & $\begin{array}{c}\text { General } \\
\text { Sales }\end{array}$ & $\begin{array}{l}\text { Motor } \\
\text { Vehicle } \\
\text { Fued }\end{array}$ & $\begin{array}{l}\text { Alcoholic } \\
\text { Beverage }\end{array}$ & Tobacco & Total & $\begin{array}{c}\text { Total } \\
\text { of All } \\
\text { Collections }\end{array}$ & $\begin{array}{l}\text { Accounted for } \\
\text { by Four Major } \\
\text { Types of } \\
\text { Sales Taxes }\end{array}$ \\
\hline $1925^{(a)}$ & 一 & $87 \cdot 4$ & 一 & (b) & 87.4 & Iro7.4 & 8 \\
\hline $1930^{(4)}$ & $\mathrm{I} .2$ & 468.6 & - & 10.5 & 480.3 & 1780.3 & 27 \\
\hline $193^{(2)}$ & $\mathrm{I} \cdot 3$ & $5 \times 9.6$ & - & 17.6 & $53^{8.5}$ & I619.3 & 33 \\
\hline I937 ... & $434 \cdot 4$ & 721.8 & 177.0 & $54 \cdot 4$ & 1387.6 & 3013.5 & 46 \\
\hline r938 & 446.8 & 777.2 & 174.7 & $55 \cdot 4$ & I $454 . I$ & $3 \times 32.4$ & $4^{6}$ \\
\hline r939 & $440 . x$ & 800.9 & $174 \cdot 3$ & 59.5 & I 474.8 & 3085.0 & 48 \\
\hline 1940 & 490.2 & $845 \cdot 4$ & 200.0 & 97.1 & 1632.7 & $3327 \cdot 2$ & 49 \\
\hline
\end{tabular}

(a) Local shares not included.

(b) Not separately reported.

Source: United States Burcau of the Census, State Tax Collections (I940) 29 and 30.

Although the data are not strictly comparable throughout, the trend is clear; an ever-increasing share of state tax collections has been accounted for by general and selective sales taxes. In spite of the fact that during the fifteen-year period all state tax collections increased three-fold, the yields from these sources rose even more rapidly.

*B.A., r916, M.A., 1923, Ph.D., x930, Ohio State University. Associate Professor of Economics, Ohio State University. Member of Staff, Governor's (Cooper) Committee on Taxation, 1930; Adviser, Joint Legislative Committee on Taxation (Ohio), I93I-1932; Assistant Director of Research, Ohio Tax Commission, 3933-I937; Director of Research, Ohio Tax and Revenue Commission, r938. Author, A STUDY of Income Taxes in Various States and Their Probable Yield if Applied in Ohlo (I930); Taxation of Intangible Personal Property in Selected States (1930).

† B.Sc. in Bus. Adm., I931, M.A. 1932, Ohio State University. Instructor in Economics, Ohio State University. Statistician, Tax Commission of Ohio, 1933-1938; Assistant Director of Research, Ohio Tax and Revenue Commission, 1938; Statistician, Ohio Department of Taxation, since r939. Member, American Statistical Association and National Tax Association. 
In 1925 probably about one-tenth or one-twelfth of the revenues of the states came from such taxes. Fifteen years later they were accounting for approximately onehalf of the total. The percentage of the total collections accounted for by consumer taxes has shown a very definite tendency to stabilize during recent years. It seems probable, however, that the aggregate amount of revenue from sales taxes will continue to increase.

It is to the circumstances under which this resort to consumer taxes was had that one must turn in order to understand the problems of revenue distribution which their use has raised. Concomitant with the decline, and in some cases the drying up, of existing sources of governmental revenue, the great depression created pressing demands for larger and larger expenditures by government. Two factors, therefore, led to legislation directed at the potential taxable capacity of consumption goods and services: (I) the need for replacement of revenue lost or diminished through one cause or another; (2) the need for new sources of revenue or an increase in existing sources for new functions or to meet increased demands upon preexisting functions of government. At the same time it was in large part necessary to turn to that level in the state governmental hierarchy possessing the greatest tax-gathering power. As between a state and the local units of government within its framework, the former will usually be the stronger. To the state legislative body, therefore, went the major task of tapping the comparatively undeveloped resources of consumption taxation, not alone for the requirements of the state government but as well for those of the lesser political units in the commonwealth.

Thus did consumer taxes take their rapid rise in a complex of functional and geographical considerations. Motor fuel taxes well illustrate the point. Although state-collected, the tax monies were in many jurisdictions to be shared by the highway funds of the state, the counties, the townships and the municipalities. Beyond this lay a demand that this lucrative source of tax monies be tapped to aid in supporting such new functions as the staggering ones of unemployment and old-age relief. If allocation to local political units were to be handled effectively, there were difficult choices to be made as to method; if diversion to alien purposes was to be considered, some guiding principle would be necessary. Often the two demands would be intermingled, thus adding complexity to complexity. In these circumstances, techniques for the imposition and collection of consumers' taxes constituted only a part of the problem facing the state legislative bodies. It was not enough to bring the new revenues into the state treasury; they must be dispatched to the places needed for the required purposes at the right time and in the proper amounts. Here are four independent but interacting variables around which revolve all the difficulties that arise in the distribution of collections from taxes on consumption.

\section{Aliocation of Revenues}

It is possible to distribute the revenues from the state treasury to the minor civil subdivisions by means of a system of (I) grants-in-aid, or (2) sharing. To many people the former usually connotes weakness and a lack of universality of need. 
In other words the area or subdivision receiving a grant has admitted its financial inability to support the required functions of government. Since some degree of financial stigma is attached to a request for a grant, a community may refuse to ask for assistance when such help may be in the interest of the whole commonwealth. If assistance is universally required-in a geographical sense-the tax-sharing method which has developed during the last two decades may seem to be the better solution. ${ }^{1}$ From a practical point of view, however, it makes little difference whether local governments are aided by means of grants or by means of sharing. For while the two forms of aid have different philosophical bases which might be expected to lead to different allocation formulas, in practice no hard and fast lines can be drawn between them. ${ }^{2}$

\section{Allocation Formulas}

Desirable as it may be, it is probable that no single "ideal" formula, whether applied to a system of grants-in-aid or applied to a system of sharing, can be devised which will allocate revenues collected by the state to its minor subdivisions, where they are to be assisted, in exactly the right proportions. The outline which follows is an attempt to present the more generally used bases for distributing to the local units the revenues from state-collected, locally-shared taxes.

\section{Methods of Allocating Revenues to Local Governments}

\section{Population:}

a. Total population.

b. Number of school children or a combination of number of school children multi. plied by number of days in school and generally known as average days attendance.

c. Population over or under certain ages.

d. Number of motor vehicle owners or motor vehicle registrations.

2. Valuation of property:

a. Total value of all property for preceding year.

b. Total value of property based upon the average of a number of preceding years.

c. Valuation of some particular form of property such as real estate.

d. Valuation of property according to location such as amount located inside incorporated municipalities.

3. Place of origin.

4. Area:

a. Square miles or some other unit of area.

b. Total mileage of roads of various types, such as county roads.

1 Another method of distribution which, in the opinion of the writers, merits more than the little consideration it has received is a reexamination of functions and activities of each level of government to the end that they may be redistributed. For example, the situations which give rise to the various forms of public assistance under the Social Security Program are state-vide in most cases and much can be said for inducing the state governments to take it over in its entirety. Such a course would have the great advantage of simplifying the problem of disposing of revenues earmarked or dedicated to public assistance.

${ }^{2}$ Excellent treatment of grants-in-aid will be found in BitTERMan, STATE aND FEDERAI Grants-IN-AID (1938). On tax sharing, see Hutchinson, State-Administered Locally-Shared TAxes (r93I); Tax Relations among Governmental Units (Tax Policy League, I938) Pt. III; Groves, Financing GovernMENT (I939). 


\section{Equally:}

a. Equal amounts to each subdivision within the state; generally confined to counties and townships.

6. Previous years' expenditures:

a. For all purposes.

b. Some particular purpose, such as relief.

The first three of these six methods are the most widely used throughout the nation. Many states, however, distribute motor fuel taxes on the basis of mileage or equally to both counties and townships. It is not unusual, furthermore, to find several of these methods used in combination after the revenues have been divided into parts, each part being distributed according to a different formula. For example, one-half of the yield of a tax may be distributed to the counties in the proportion that the population of each county bears to the total population of the state and the other one-half to the school districts in the proportion that the average daily attendance of the district bears to the total average daily attendance in the state as a whole. Any evaluation of the various methods of allocation must finally be dependent upon the particular tax and the purpose for which it was levied.

The allocation of the revenues from consumption taxes on the basis of total population has the advantage of being most easily understood by the people and often the most expedient politically. On the other hand, it is defective in failing to take into consideration the needs of the local subdivisions. For example, if the tax has been levied for the purpose of aiding them in the financing of relief, allocation of the revenue according to population would not take into consideration that in recent years a greater proportion of the population in large cities has been unemployed than has been true of rural areas.

Often a particular segment of the population will furnish a more logical and equitable method of distribution than will the total. If a consumption tax has been levied for the purpose of defraying the cost of public schools there is, of course, merit in distributing the money to the districts in proportion to the number of children of school age or actually attending the schools in each district. No attempt will be made to discuss equalization since it partakes of the character of a grant-inaid from state funds, thus disregarding the yield of the tax which is of most concern here.

Many of the consumption taxes enacted during the thirties were designed to replace revenues lost through the decline in the value of property, particularly tangible property. In some states they were enacted in order that the burden of taxation borne by the owner of property might be reduced. In these cases the distribution of revenues in proportion to the assessed value of property has a logical appeal. This is especially true if the appraised value of the property and the rates of taxation have been fairly uniform throughout the state. It is well known that the density of population and the value of tangible property are highly correlated. It follows that the results attained in distributing revenues either according to population or 
according to value of property will be almost the same. Since, however, a census is taken only once in a decade while appraisements are usually more frequently made, the latter method is likely to be more nearly in keeping with the economic situation at any given time.

It has been argued that the allocation of revenue on the basis of assessed valuation will place a desirable premium upon keeping such valuations near their true value. If there were no other factors affecting the appraisal of property there is no good reason to believe that this would not be the result. Actually there are many other elements to be considered in changing valuations, especially upward. There is no evidence that the objective has been attained or even approached in any given state.

The distribution of the "local government fund" in Ohio is a good illustration of the use of "valuation of property according to location" as a method of allocating revenues to local governments. When the retail sales tax was first levied in r935, 40 per cent of the revenue was placed in the "local government fund" after certain fixed appropriations had been deducted. Since 1939 , \$12,000,000 of sales tax revenue each year has been placed in the local government fund. This fund has always been distributed among the counties according to the ratio of the tangible property inside incorporated municipalities of a county to the total value of tangible property inside incorporated municipalities within the state. This method tends to distribute the major portion of the fund to the eight large urban counties. In fact these counties receive approximately 70 per cent of the fund although they only account for about one-half of the population of the state.

Wealthy communities are very insistent that local shares be allocated on the basis of "origin." Every federal, state and local tax administrator has had to meet this issue at one time or another. One often hears it stated that if New York or Pennsylvania or Ohio received from the Federal Government all the tax monies the residents of those states pay in to the federal treasury there would be no difficulty in financing the state and local governmental functions within them. Similarly, the officials of municipal governments within whose boundaries retail establishments are most likely to be found will insist that revenues collected from taxes on retail sales should be returned to them. They forget that their municipality is a market center for individuals who dwell in communities which must maintain governmental services but which have no market outlets. There is involved in this reasoning the assumption that the incidence of the tax is upon the vendor, an assumption most difficult to defend in the case of consumer taxes. ${ }^{3}$ The adherents of this method have relied almost solely upon political appeal, probably realizing that any attempt to give it a sound theoretical basis would be a feeble one.

At the present time there seems to be little defense for using area as a basis for allocating funds. No doubt hypothetical situations could be devised which would

\footnotetext{
${ }^{3}$ On the incidence and ultimate impact of consumption taxes, see Martin, Distribution of the Consumption Tax Load, supra this issue.
} 
give support to this method. In rural areas requiring the same type of highway and where mileage varies directly with area, it might be defended. But few areas today would even approximate these conditions. Another method similar to that based upon area but with much more to recommend it is that sometimes used in distributing the revenues from motor fuel taxes. This method is to allocate according to the mileage which exists within the boundaries of a given governmental unit. If the traffic density and the type of surface within the area are the same throughout, it furnishes an excellent basis for allocating the revenues. Furthermore, and this is no mean advantage, it is easily understood by the taxpayer.

The equal distribution of funds among local governments seems absolutely unwarranted. At best it can be supported only from the point of view of expediency and when used in combination with some other method. It is well illustrated in the distribution of the motor vehicle license tax in Ohio. After certain deductions for claims and administration, the state highway department receives 23 per cent of the revenue, the counties receive 47 per cent allocated on the basis of motor vehicle registration, the municipalities receive 25 per cent on the same basis, and the remaining 5 per cent is distributed equally among the 88 counties.

As a general rule the most economical use of tax revenues will not result if they are distributed in proportion to previous years' expenditures. Those expenditures have been in part accidental or nonrecurrent. Furthermore, this method may encourage unnecessary expenditures just to get a greater share of the state-collected tax revenue. Most important of all, it does not recognize the need of the governmental unit. It is possible that the unit requiring the most assistance would be the one where expenditures, because of lack of funds, had been kept at a minimum; while in some other unit the expenditures would be unnecessarily high simply because the revenue was available.

\section{Extent of Allocation}

The multiplicity of formulas must not be allowed to obscure the fact that, as Table II forcefully shows, local governments today share significantly in statecollected consumer taxes. The table reveals that, in 1940, out of nearly one and twothirds billion dollars derived from state-collected consumer taxes, approximately I4 per cent found its way back to the local governments. Furthermore, this is the minimum since the Bureau of the Census, which compiled the data, in some instances, classified "collections 'For State' because they are first deposited in funds containing receipts from several sources, and are therefore considered as grants from unspecified sources" although they may have been "reported by state officials as apportioned to local units."

The absence of general sales taxes is notable in the case of the New England states. This section of the country apparently relies to a considerable extent upon its state governments to perform the services desired. This is brought out by the fact that Massachusetts is the only state in the section which apportions any of the 
TAbLe II

Revenue and Allocation from Sales Taxes, by State, i940

(In thousands of dollars)

\begin{tabular}{|c|c|c|c|c|c|c|c|c|c|c|c|c|c|c|}
\hline \multirow{2}{*}{$\begin{array}{l}\text { Divirion and } \\
\text { State }\end{array}$} & \multicolumn{3}{|c|}{ Total Revenues } & \multicolumn{3}{|c|}{ General Sales } & \multicolumn{3}{|c|}{ Motor Fuel } & \multicolumn{3}{|c|}{ Alcoholic Beverages } & \multirow{2}{*}{$\begin{array}{c}\text { To- } \\
\text { bacco } \\
\text { Pro- } \\
\text { ducts } \\
\end{array}$} & \multirow{2}{*}{$\begin{array}{c}\text { All } \\
\text { Other }\end{array}$} \\
\hline & Total & State & Local & Total & State & Local & Total & State & Local & Total & State & Local & & \\
\hline 1028 & $\$ 1,647,376\}$ & $\$ 1,415,392$ & $\$ 231,981 \$$ & $\$ * 90,188 \mid$ & 459,860 & $\$ 30,32$ & $\$ 845,423$ & $\$ 665,574$ & $\$ 179,849$ & $\$ 199,969$ & $\$ 178,561$ & $\$ 21,408$ & 897,05 & 4,746 \\
\hline New Enplan & 77,140 & 70,024 & 7,116 & - & - & - & 48,131 & 41,015 & 7,116 & 15,577 & 15,577 & - & 13,192 & 240 \\
\hline Maine... & 7,399 & 7,399 & - & - & - & - & 6,133 & 6,133 & - & 1,165 & 1,165 & 一 & $\rightarrow$ & 101 \\
\hline & 5,381 & 381 & - & - & - & - & 3,746 & 3,746 & - & 560 & 560 & - & 1,075 & - \\
\hline & 4,169 & 4,169 & - & - & - & - & 2,703 & 2,703 & 一 & 965 & 965 & - & 501 & 一 \\
\hline & 36,963 & 29,847 & 7,116 & 一 & - & - & 21,134 & 14,018 & 7,116 & 8,329 & 8,329 & - & 7,361 & 139 \\
\hline & 17,980 & 17,980 & - & 一 & - & - & 10,568 & 10,568 & - & 4,558 & 4,558 & - & 2,854 & - \\
\hline & 5,248 & 5,248 & - & - & - & - & 3,847 & 3,847 & - & - & - & - & 1,401 & - \\
\hline lidd & $242,851]$ & 208,819 & 34,031 & 8 & 8) & - & 151,210 & 130,085 & 21,125 & 57,782 & 44,876 & 12,906 & 33,513 & 338 \\
\hline & 126,899 & 105,127 & 21,772 & 1 & 1 & - & 70,930 & 62,064 & 8,866 & 34,160 & 21,254 & 12,906 & 21,530 & 278 \\
\hline & 32,661 & 27,528 & 5,133 & - & - & - & 23,272 & 18,139 & 5,133 & 9,329 & 9,329 & - & - & 60 \\
\hline & $\$ 3,291$ & 76,164 & 7,126 & 7 & 7 & - & 57,008 & 49,882 & 7,126 & 14,293 & 14,293 & - & 11,983 & - \\
\hline Sast & 463,308 & 394,627 & 68,681 & $|225,715|$ & 213,715 & 12,000 & 171,593 & 118,553 & 53,040 & 52,144 & 48,514 & 3,630 & 11,568 & 2,288 \\
\hline $\mathrm{Oh}$ & 138,869 & 110,405 & 28,465 & 50,985 & 38,985 & 12,000 & 51,428 & 34,963 & 16,465 & 26,083 . & 26,083 & - & 8,679 & 1,694 \\
\hline & 53,020 & 44,523 & 8,497 & 23,538 & 23,538 & - & 24,565 & 16,068 & 8,497 & 4,917 & 4,917 & - & - & - \\
\hline & 145,599 & 124,059 & 21,539 & 90,818 & 90,818 & - & 43,687 & 22,159 & 21,528 & 10,502 & 10,502 & - & - & 591 \\
\hline & 95,909 & 89,359 & 6,550 & 60,374 & 60,374 & - & 31,243 & 24,693 & 6,550 & 4,290 & 4,290 & - & - & 3 \\
\hline & 29,911 & 26,281 & 3,630 & - & - & - & 20,670 & 20,670 & - & 6,352 & 2,722 & 3,630 & 2,889 & - \\
\hline West A & 156,879 & 124,738 & 32,141 & 57,561 & 41,788 & 15,773 & 78,939 & 63,322 & 15,617 & 15,484 & 15,119 & 365 & 4,642 & 253 \\
\hline & 23,631 & ,416 & 6,215 & - & - & - & 18,646 & 12,431 & 6,215 & 4,985 & 4,985 & - & - & - \\
\hline & 37,064 & 22,561 & 14,502 & 16,859 & 7,437 & 9,422 & 16,771 & 11,691 & 5,080 & 1,166 & 1,166 & - & 2,177 & 91 \\
\hline & 41,723 & 41,723 & - & 23,019 & 23,019 & - & 13,904 & 13,904 & - & 4,674 & 4,674 & - & - & 126 \\
\hline & 7,067 & 5,938 & 1,129 & 3,099 & 3,099 & - & 2,292 & 1,528 & 76 & 1,133 & 768 & 365 & 510 & 33 \\
\hline & 11,839 & 839 & - & 4,504 & 4,504 & 一 & 5,412 & 5,412 & - & 1,258 & 1,258 & - & 662 & 3 \\
\hline & 13,598 & 10,040 & 3,558 & - & - & - & 11,860 & 8,302 & 3,558 & 1,738 & 1,738 & - & - & 一 \\
\hline & 21,957 & 15,221 & 6,737 & 10,080 & 3,729 & 6,351 & 10,054 & 10,054 & - & 530 & 530 & - & 1,293 & - \\
\hline Sotut & 188,632 & 166,864 & 21,768 & 30,816 & 30,816 & - & 128,272 & 109,379 & 18,893 & 20,645 & 17,770 & 2,875 & 5,385 & 3,514 \\
\hline & 2,862 & 2,862 & - & - & - & - & 2,205 & 2,205 & - & 619 & 619 & - & - & 38 \\
\hline & 16,791 & 14,826 & 1,965 & - & - & - & 11,231 & 9,266 & 1,965 & 4,362 & 4,362 & - & - & 1,198 \\
\hline & 19,869 & 19,549 & 320 & - & - & - & 18,236 & 17,916 & 320 & 1,633 & 1,633 & - & - & - \\
\hline & 30,438 & 438 & - & 18,608 & 18,608 & - & 10,690 & 10,690 & - & 1,140 & , 140 & - & - & - \\
\hline & 40 & 16) & - & 12,208 & 12,208 & - & 46 & 46 & - & 2,162 & 2,162 & - & - & - \\
\hline & 20,595 & 589 & 5,006 & - & - & - & 12,839 & 08 & 2,131 & 3,010 & 135 & 2,875 & 2,559 & 2,187 \\
\hline & 27,990 & 24,513 & 3,477 & - & - & - & 21,614 & 18,137 & 3,477 & 3,459 & 3,459 & - & 2,826 & 91 \\
\hline & 29,771 & 18,771 & 11,000 & - & - & - & 25,511 & 14,511 & 11,000 & 4,260 & 4,260 & - & - & - \\
\hline Eas & 95,332 & 75,450 & 19,882 & 14,502 & 13,452 & $1,050^{\mathrm{j}}$ & 60,524 & 42,609 & 17,915 & 6,939 & 6,022 & 917 & 10,637 & 2,730 \\
\hline & 20,976 & 20,976 & - & & & - & 13,458 & 13,458 & - & 3,908 & 3,908 & - & 1,724 & 1,883 \\
\hline & 24,598 & 18,190 & 6,408 & - & - & - & 664 & 14,173 & 5,491 & 1,949 & 1,032 & 917 & 2,893 & 92 \\
\hline & 26,792 & 18,139 & 8,653 & 7,756 & 6,706 & 1,050 & 01 & 598 & 7,603 & 359 & 359 & - & 3,344 & 32 \\
\hline & 22,966 & 5 & 4,821 & 6,743 & 6,743 & - & 101 & 7,280 & 4,821 & 723 & 723 & - & 2,676 & 723 \\
\hline Wes & 145,274 & 136,306 & 8,966 & 23,939 & 22,434 & 1,505 & 89,707 & 82,876 & 6,831 & 12,316 & 11,685 & 631 & 15,651 & 3,661 \\
\hline & 20,563 & 311 & 1,252 & 5,514 & 5,514 & - & 13 & 9,761 & 1,252 & 2,422 & 2,422 & - & 1,593 & 21 \\
\hline & 35,785 & 3 & 4,112 & 7,473 & 5,968 & 1,505 & 251 & 644 & 2,607 & 3,078 & ,078 & - & 4,672 & 2,311 \\
\hline & 29 & & 3,602 & 10,952 & 10,952 & - & 95 & 23 & 2,972 & 661 & 30 & 631 & 2,182 & 1,329 \\
\hline & 59,307 & 07 & - & - & - & - & 45,948 & 45,948 & - & 6,155 & 6,155 & - & 7,204 & - \\
\hline$M_{0}$ & 07,197 & 61,951 & 5,246 & 23,178 & 23,178 & - & 37,288 & 32,042 & 5,246 & 6,041 & 6,041 & - & 359 & 331 \\
\hline & 5,795 & 5,795 & - & - & - & - & 5,030 & 5,030 & - & 753 & 753 & - & 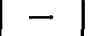 & 12 \\
\hline & 5,570 & 70 & 1,000 & - & - & - & 81 & 4,281 & 1,000 & 222 & 222 & - & - & 67 \\
\hline & 5,044 & 55 & 689 & 1,961 & 1,961 & - & 2,756 & 2,067 & 689 & 327 & 327 & - & - & - \\
\hline & 20,598 & 18,424 & 2,174 & 8,810 & 8,810 & - & 9,252 & 7,078 & 2,174 & 2,306 & ,306 & - & - & 230 \\
\hline & 9,892 & 9,892 & - & 4,198 & 4,198 & - & 4,975 & 4,975 & - & 719 & 719 & - & 一 & - \\
\hline & 10,018 & 8,635 & 1,383 & 4,010 & 4,010 & - & 4,610 & 3,227 & 1,383 & 1,398 & 1,398 & - & - & - \\
\hline & 8,571 & 8,571 & - & 4,199 & 4,199 & - & 3,874 & 3,874 & - & 117 & 117 & - & 359 & 22 \\
\hline & 1,709 & 1,709 & - & - & - & - & 1,510 & 1,510 & - & 199 & 199 & - & - & - \\
\hline acifs & 210,763 & 176,613 & 34,150 & 114,469 & 114,469 & 一 & 79,759 & 45,693 & 34,066 & 13,041 & 12,957 & 84 & 2,103 & 1,391 \\
\hline & 42,547 & 33,375 & 9,172 & 20,689 & 20,689 & - & 16,234 & 7,062 & 9,172 & 2,130 & 2,130 & - & 2,103 & 1,391 \\
\hline & 12,982 & 12,898 & 84 & - & - & - & 12,381 & 12,381 & - & 601 & 517 & 34 & - & - \\
\hline & 155,234 & 130,340 & 24,894 & 93,780 & 93,780 & 一 & 51,144 & 26,250 & 24,894 & 10,310 & 10,310 & 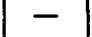 & 一 & - \\
\hline
\end{tabular}

Source: U. S. Bureau of the Census, State Tax Collections (1940) 16 and 17. 
revenue from consumer taxes to its local units, and this is true only for motor fuel taxes. Rhode Island is the only commonwealth which does not collect taxes on alcoholic beverages. All but seven of the states retain the collections from the lastnamed source for their own purposes. Over one-half (25) of the states levy taxes on tobacco products and Kansas is the only state sharing with localities according to the classification established by the Bureau of the Census. Peculiarly enough, all eight of the South Central states levy tobacco taxes. In no other section of the country does every state impose this type of tax. It is interesting to note that sharing is most nearly nation-wide and greatest in the case of the revenues from motor fuel taxes. In fact well over one-fifth of the receipts from this source find their way back to local units although only 30 of the 48 states apportion any of these revenues to their minor subdivisions.

The revenue from the motor fuel tax accounted for slightly over one-half of the total collections from consumer taxes in r $94^{\circ}$. General sales taxes ran a poor second but it must be kept in mind that some of the wealthiest states in the Union, the New England and Middle Atlantic states, did not make use of them. This is forcefully brought out by noting the revenues which they collect from other types of taxes on consumer goods. Nearly one-fourth of the motor fuel tax revenues, over one-third of those from alcoholic beverages and nearly one-half of those from tobacco products are collected from the nine states in these two sections.

If state governments share the receipts from consumer taxes with their local subdivisions to the extent, on the average, of about one-seventh, stated inversely about six-sevenths is retained by the states. The percentage of the total collections withheld by the various state governments in 1940 is shown in Table III, which should be read in connection with Table II.

The West North Central and the East South Central sections of the nation were the most liberal with their subdivisions. On the average these states, of which there are eleven, sent more than one-fifth of the collections back to their local units although three of them did not return one red cent. Iowa returned nearly two-fifths and Florida nearly three-eighths to rank first and second from the point of view of sharing. The citizens of the local governments of the four West South Central states probably felt that their state governments were extremely parsimonious. They received slightly less than one dollar out of sixteen collected from consumers. The Mountain and New England state governments retained, on the average, over 90 per cent of the collections in their own treasuries. ${ }^{4}$ Exactly one-third (I6) of the states kept all receipts for their own use.

It should be clear from Tables II and III that the revenues from state-collected consumer taxes which are being distributed to local governments are quite sufficient in amount to warrant concern over the problem of sharing. But sharing is only one of the difficulties to be faced in the distribution of revenues. It is possible to

\footnotetext{
"At the November, 1940, elections, Arizona, retaining 86 per cent of all consumption taxes collected by it, and Oklahoma, retaining 88 per cent, both rejected initiated proposals for greater sharing of gasoline taxcs. Sce (I94I) 30 NAT. Mun. Rev. I22.
} 
TAble III

Per Cent of All Consumption Taxes Actually Retained by State

GoverNMENTS, I940

\begin{tabular}{|c|c|c|c|}
\hline $6 r \%$ to $70 \%$ & $7 x \%$ to $80 \%$ & $81 \%$ to $90 \%$ & $91 \%$ to $100 \%$ \\
\hline Alabama ....... & 68 Minnesota ..... & Arizona ....... 8 & Arkansas ...... 94 \\
\hline Florida & 63 Mississippi & California & Connecticut \\
\hline Iowa & 6r Nebraska. & Colorado & Delaware ..... roo \\
\hline Kansas & 69 Ohio & Georgia . & Kentucky ...... I00 \\
\hline & South Carolina & Idaho. & Maine .... \\
\hline & Tennessee ...... 74 & Illinois & Michigan $\ldots \ldots \ldots 93$ \\
\hline & Washington $\ldots .78$ & Indiana & Missouri .. \\
\hline & & Louisiana & Montana ........ I00 \\
\hline & & Maryland & Nevada ....... roo \\
\hline & & Massachusetts & New Hampshire. I00 \\
\hline & & New Jersey & New Mexico ... I0o \\
\hline & & New York & North Carolina...roo \\
\hline & & North Dakota & Oregon $\ldots \ldots \ldots 99$ \\
\hline & & Oklahoma & Pennsylvania ... 9r \\
\hline & & Wisconsin & Rhode Island ... I0o \\
\hline & & Wyoming & South Dakota . . . xoo \\
\hline & & & Texas ......... \\
\hline & & & Utah ......... roo \\
\hline & & & Vermont ..... roo \\
\hline & & & Virginia $\ldots \ldots \ldots 98$ \\
\hline & & & West Virginia . . roo \\
\hline
\end{tabular}

4

I6

$2 I$

Source: Table II.

direct the yield from a given tax to a specific function with or without sharing. That is, the state may "earmark" the receipts for a clearly defined function such as highways and, at the same time, not allocate them to its minor subdivisions. It is interesting to note, however, that the terms, earmarking and allocation, are tending to become synonymous in many respects. If the central government institutes a policy of sharing revenues it will usually not be long until local government authorities will begin to insist that the shared revenues were originally earmarked for these governments.

\section{EARMARKING OF REVENUES}

Earmarking seems historically to have been in large part the result of accident rather than of design and is much older than recent controversy would seem to indicate. No doubt, the opinion held in this country that earmarking is a development of the last two decades grows out of the fact that, as a general policy, the Federal Government has not resorted to it.- The constitutional requirement that direct taxes-not the revenue therefrom-must be apportioned among the states according to population immediately became an effective barrier to their use. Congress was compelled, therefore, to resort to customs and internal revenue duties to 
obtain revenue sufficient to carry on the functions of government. A tariff law was enacted as early as July 4, I789, and every school child recalls that President Washington called out the National Militia, in I794, to quell the "Whiskey Rebellion." Some of the federal excises have had as their aim the regulation or restriction of the use of certain commodities rather than the production of revenue; but none has been earmarked for a specific function of government.

It is nevertheless true that, even as early as the time the Constitutional Convention met in 1787 , earmarking was practiced in England. Historians of taxation will recall that one of the difficulties facing Pitt the Younger in the seventeen-eighties was the confusion in the public accounts. This was largely the result of the fact that receipts from taxes on selected commodities were used for specific purposes. In many cases several different levies were charged on the same commodity and the revenue from each levy earmarked for a different purpose. It can hardly be assumed, therefore, that the Founding Fathers were not acquainted with earmarking and it is probably a tribute to them that they wrote no such requirement in the organic law of our nation.

Although earmarking could be found before I920, it was about that time that the present cycle seems to have started. Here and there ono can find a few indications that the peak has been reached and that it may be on the decline. Doubtless the change in economic conditions brought about by World War I was largely responsible for the return to earmarking. The situation was especially noticeable in the rapid development of a comparatively new means of transportation. The number of motor vehicles was increasing by leaps and bounds, resulting in an enormously increased demand for better streets and highways. The mainstay of highway finance up to this time had been the taxes on property, especially real estate. During the nineteen-twenties real property values, particularly in rural areas, declined rapidly while the revenue demands of practically all functions of government increased. It seemed obvious that new sources of revenue must be found if the demands of highway users were to be satisfied. What could be better than a tax placed upon the motorist who would benefit from the improved highways? Generally, he raised no objection provided the tax which he paid to the government was used solely for his benefit.

The issue thus precipitated is often confused by the introduction of the "benefit" theory of taxation into the controversy. This is especially true in the case both of motor fuel and motor vehicle license taxes. No doubt the emphasis on "benefit" is largely the result of the attempts to make the gasoline tax palatable to the motorist. In this sense the gasoline tax and the motor vehicle license tax partake of the nature of a special assessment when used for highways; to the extent that revenues from these two sources are used for purposes other than highways they are similar to other taxes. This point can be illustrated and clarified from the situa- 
tion in Ohio with respect to motor vehicles during the early part of the last decade. In I93 the General Assembly of Ohio, in revising its tax system, especially that relating to personal property, removed motor vehicles from the property tax duplicate. At the same time it also increased the license fees on automobiles with the provision that, temporarily, a part of the revenue from this source was to be used for replacement of the revenues lost by their removal from the duplicate. Strictly, a passenger car owner purchasing a set of tags for his auto in I932 paid for three things: (I) regulation; (2) a special assessment for the súpport of highways; and (3) a property tax, the revenue from which was to be used for the support of the general functions of government.

If the line of development stated above is sound, the case for and against earmarking stands or falls according to the respective merits of the arguments for and against special assessments. ${ }^{5}$ If it is granted that some or all of the revenue from a certain source really belongs in a category similar to special assessments then it follows that those revenues should be earmarked for a specific purpose. Clearly the one who receives the benefit should pay and the payments which he makes should not be diverted to some other use. The automobile owner requires a much better road than does the owner of a horse-drawn vehicle, and this difference should be charged to him. Where benefit can be clearly allocated earmarking seems justifiable. This does not mean, however, that another tax, general in its application, should not be imposed upon the commodity. There is no good reason why a tax should not be placed upon motor fuel and earmarked for highway purposes and, at the same time, a second tax placed upon retail sales including those of motor fuel for the general functions of government.

Many instances could be enumerated where the yields from certain taxes have been earmarked and where the individual or group paying the tax receives no special benefit. Michigan, by constitutional provision, has long earmarked receipts from inheritance and certain other taxes for schools while Colorado, by the same means, guarantees that 85 per cent of the revenue from sales, use, and liquor taxes will be used for old age pensions. Ohio has, in the past, by statute, earmarked for schools the revenue from taxes on certain intangibles, cigarettes and liquid fuel. To the questions whether cigarette smokers in Ohio receive greater benefit from schooling than do cigar smokers or nonsmokers who do not pay the tax, or why the yields from these sources were dedicated to a particular activity, the only answer that can be given is that of expediency. Revenues were required and these sources were easily tapped. These requirements may have arisen out of a demand for replacement of revenue lost either ( $I$ ) through a limitation of the tax rate by constitutional amendment or legislative enactment, or (2) through a narrowing of the tax base

\footnotetext{
${ }^{\circ}$ An excellent summary of the arguments for and against earmarking revenues will be found in New York State Tax Comm., Ann. Rep. (1937) 24-28.
} 
by the same means, or (3) by the establishment of mandatory levies usually through property tax rates limiting the amounts available to those levels or functions of government which do not have the good fortune to hold mandatory rates, or finally (4) by a decline or delinquency in existing taxes.

The evils of earmarking in cases where "benefit" cannot be clearly shown is well brought out by the retail sales tax in Ohio. As a result of continuing delinquency of real property taxes, of the ten-mill amendment to the state constitution, and of the demand for funds to take care of relief and the schools, the need for additional revenue became imperative. A retail sales tax was enacted in 1934, effective January, 1935. The revenue from this source was earmarked for relief, aid to the aged, schools and local governments. The last two were residual claimants since they shared 40 per cent and 60 per cent, respectively, in any balance after the other claims had been met. During the second year of operation, their shares were quite large, reaching about $\$ 17,000,000$ in the case of local governments and some $\$ 26,000,000$ for schools. After the exemption of food by constitutional amendment these shares dropped very sharply and the recession of 1938 brought another decline. The cumulative effect of these decreases was to bring a deficit in the "School Foundation Program" of about \$18,000,000. A change being absolutely necessary, in 1939 the General Assembly discontinued earmarking in large part and turned to the fixed appropriation method. While at the time this change brought little objection, local government officials have, at the present session, contended that revenue from the retail sales tax is being diverted. Obviously, the contention that diversion is taking place is a result of the increasing revenue that is being drawn from this source. To support their position these local officials point out that the sales tax was enacted to replace the losses suffered under the ten-mill amendment.

The situation in Ohio also illustrates very well the difficulties that may be encountered when a revenue source is earmarked for a specific function which must be carried on during depressions, tecessions, booms and so on. If the function depends solely or very largely upon the earmarked source it should logically be possible to contract it and to expand it concurrently with the changes in the yield of the earmarked tax. But Ohio schools had to be supported regardless of the yield of the sales tax with the result that a series of recurring deficits appeared. In the case of highways the problem is somewhat different. So long as funds are available to maintain them at a definite level, however high or low, the situation is no worse. When revenues increase any surplus over maintenance can be devoted to new construction, and when this surplus decreases or ceases to exist construction can be contracted in proportion. 
Diversion of Revenues and Attempts to Restrict It

It should be clear that diversion of revenues cannot take place unless prior to its existence the funds have been earmarked. During the last two decades a curious situation has developed. The increased requirements of some function of government or decreases in existing revenues have led to the tapping of new sources. This, in turn, has led to earmarking the new funds for a given function or for a given level of government, followed in the last stage by successful or unsuccessful attempts to divert to other uses the earmarked revenues. Diversion is thus an outgrowth of earmarking. Again the similarity to the special assessment becomes obvious. Legislative bodies are usually prohibited by constitutional provisions from using the yield from a special assessment for any purpose other than that specified in the petition for the assessment. Those opposed to diversion could in many cases have clarified the issue had they pointed out the similarity between earmarking and the special assessment.

There are instances where the cry of diversion seems unwarranted although the tax enacted can be condemned on other grounds. A beautiful illustration of this occurred in Ohio in 1933 when the General Assembly removed one cent from the motor fuel tax and placed a tax of one cent on liquid fuel. The revenues from this source were earmarked for public schools. The motorist and the producer and purveyor of gasoline began to cry that the gasoline tax was being diverted. Nothing could be further from the truth since this was a separate tax for a quite different purpose. They might well have asked, however, if the consumer of liquid fuel received a benefit from public schools not granted to nonconsumers. Their attack should have been from the vantage ground of the special assessment and not from that of diversion. Had the state government used for highway construction the revenue from the liquid fuel tax which was dedicated to the schools, then a true case of diversion would have been present.

The issue of diversion has been more discussed and has received more publicity in connection with motor fuel taxation than in all other connections combined. By I929 all forty-eight states and the District of Columbia imposed a tax on gasoline. As the ensuing depression deepened, legislators and others noted that revenue from this source tended to remain constant or declined very little, while the yield from other tax sources decreased sharply or almost dried up. The inevitable reaction was to use some of this revenue to support the general functions of government. The following table is more eloquent as to the result than words could be: 


\section{TABLE IV}

Gasoline Tax Revenues Disbursed and Amount and Pencentage Diverted for NonHighway Purposes, United States, Annually, 1925-1939

(Thousands of dollars)

\begin{tabular}{|c|c|c|c|}
\hline \multirow[b]{2}{*}{ Year } & \multicolumn{2}{|c|}{ AMount of Revenue } & \multirow{2}{*}{$\begin{array}{l}\text { Percentage } \\
\text { Diverted }\end{array}$} \\
\hline & Disbursed $^{\mathrm{a}}$ & Diverted & \\
\hline $1925^{\circ}$ & $\ldots \$ 146,029$ & $\$ 6,436$ & 4 \\
\hline I926 & $\ldots \ldots \ldots \ldots \ldots \ldots \ldots \ldots \ldots \quad$ I87,603 & 3,521 & 2 \\
\hline I927 & ……............. $25^{8,967}$ & $5,33^{8}$ & 2 \\
\hline x928 & . & 8,346 & 3 \\
\hline I929 & 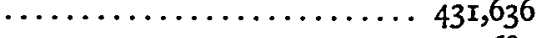 & 10,316 & 2 \\
\hline I930 & 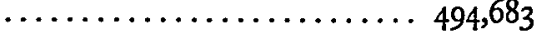 & 15,154 & 3 \\
\hline I93I & $\ldots \ldots \ldots \ldots \ldots \ldots \ldots \ldots \ldots \ldots \ldots \ldots \ldots \ldots+537,590$ & 18,575 & 3 \\
\hline I932 & $\ldots \ldots \ldots \ldots \ldots \ldots \ldots \ldots \ldots 5^{14,4,139}$ & 47,570 & 9 \\
\hline r933 & $\ldots \ldots \ldots \ldots \ldots \ldots \ldots \ldots \ldots 5^{19,403}$ & 54,766 & II \\
\hline x934 & $\cdots \cdots \cdots \cdots \cdots \cdots \cdots \cdots \cdots \cdots \cdots 5^{65, r_{40}}$ & 88,927 & 16 \\
\hline I935 & $\ldots \ldots \ldots \ldots \ldots \ldots \ldots \ldots \ldots 6^{6} 5,58 \mathrm{I}$ & Iro, $47 \mathrm{I}$ & 18 \\
\hline 1936 & . $\ldots \ldots \ldots \ldots \ldots \ldots \ldots \ldots \ldots 683,074$ & $\operatorname{xr} 9,408$ & 17 \\
\hline r937 & $\cdots \cdots \cdots \cdots \cdots \cdots \cdots \cdots \cdots \cdots \cdots, 768$, oro & II9,404 & 16 \\
\hline I938 & …................ $7^{69,313}$ & 121,257 & 16 \\
\hline r939 & $\ldots \ldots \ldots \ldots \ldots \ldots \ldots \ldots \ldots, 809, \mathrm{r} 76$ & 136,382 & 17 \\
\hline
\end{tabular}

a Disbursements rather than collections are used in order to furnish a comparable base for diversion.

b There was probably some diversion before 1925 but no accurate information is available.

Source: Adapted from Petroleum: Facts and Figures (6th ed. 1939) 133; and Federal Works Agency, Public Roads Administration, table issued September, 1940.

Down to the time of the depression some diversion took place but it was negligible. In fact it was not until the seriousness of the economic situation came to be realized that diversion began to be practiced in earnest. Following r93r the amounts diverted rose much more rapidly than disbursements. The peak of diversion was reached relatively in 1935, since which time diversion has shown a tendency to stabilize at about one-sixth of the total disbursements. Without doubt the Hayden-Cartwright Act, discussed in a closing paragraph, has been a stabilizing influence as well as the ratification, in several states, of constitutional amendments which prevent diversion.

The general funds of the various governmental units profited most from gasoline tax diversion in 1939 , as is indicated by the table below. New York state alone accounted for almost exactly one-half going to general funds, with Pennsylvania a very poor second and Ohio a lagging third. Education was second in the gasoline bread-line but it got only about one-fourth as much as did the general funds. Texas accounted for half of the diversion to education. Relief was next in line after education, a little less than $\$ 5,000,000$ behind it. The largest amount diverted to relief was $\$ 4,385,000$ in Illinois, with New Jersey, California and Louisiana following in the order named.

Of the thirty states diverting some motor fuel tax revenue, Arizona was the least guilty from the point of view of the actual amount while New York was the worst offender. Twenty states and the District of Columbia placed some gasoline tax 


\section{TABLE $V$}

\section{Disposition of State Motor Fuel Tax Receipts, By State, r939}

(In thousands of dollars)

\begin{tabular}{|c|c|c|c|c|c|c|c|c|c|c|}
\hline \multirow[b]{2}{*}{ State } & \multicolumn{4}{|c|}{ Highway Purposes } & \multicolumn{5}{|c|}{ Non-Highway Purposes } & \multirow[b]{2}{*}{$\begin{array}{l}\text { Grand } \\
\text { Total }\end{array}$} \\
\hline & $\begin{array}{l}\text { State } \\
\text { High- } \\
\text { ways } \\
\end{array}$ & $\begin{array}{c}\text { Local } \\
\text { Roads } \\
\text { and } \\
\text { Streets }\end{array}$ & $\begin{array}{c}\text { Other } \\
\text { Highwa } \\
\text { Pur- } \\
\text { poses }\end{array}$ & Total & $\begin{array}{c}\text { General } \\
\text { Funds }\end{array}$ & Relief & $\begin{array}{c}\text { Educa- } \\
\text { tion }\end{array}$ & Other & Total & \\
\hline TOTAL. & $\$ 482,483$ & $\$ 188,005$ & $\$ 2,846$ & $\$ 673,334$ & $\$ 92,430$ & $\$ 17,489$ & $\$ 22,398$ & 84,065 & $\$ 136,382$ & $\$ 809,716$ \\
\hline Neto England.. & 27,219 & 13,640 & 1,285 & 42,144 & 2,507 & 1,389 & - & 22 & 3,918 & 46,062 \\
\hline Maine.. & 5,100 & 602 & - & 5,702 & - & - & - & - & - & 5,702 \\
\hline New Hamp & 2,738 & 769 & - & 3,507 & - & - & - & 一 & - & 3,507 \\
\hline Vermont. . & 1,693 & 962 & 6 & 2,661 & - & - & - & 15 & 15 & 2,676 \\
\hline Massachuse & 6,281 & 11,272 & 1,239 & 18,792 & - & 1,389 & - & & 1,396 & 20,188 \\
\hline Rho & 1,434 & 35 & 40 & 1,509 & 2,507 & - & - & - & 2,507 & 4,016 \\
\hline Connecticu & 9,973 & - & - & 9,973 & - & - & - & & - & 9,973 \\
\hline Middle Atlantic. & 57,209 & 25,940 & 812 & 83,961 & 63,844 & 3,290 & 580 & 694 & 68,408 & 152,369 \\
\hline New Yorkł. & 13,245 & 10,227 & 460 & 23,932 & 45,983 & - & - & - & 45,983 & 69,915 \\
\hline New Jerse & 10,426 & 5,033 & 257 & 15,716 & $\dagger \quad 3,000$ & 3,290 & 580 & 489 & 7,359 & 23,075 \\
\hline Pennsylvan & 33,538 & $10,6 \mathrm{~s} 0$ & 95 & 44,313 & 14,861 & - & - & 205 & 15,056 & 59,379 \\
\hline East North Centro & 77,012 & 57,392 & 141 & 134,545 & 15,209 & 4,385 & 3,921 & 一 & 23,515 & 158,060 \\
\hline Ohio....... & 20,082 & 15,529 & - & 35,611 & 11,463 & - & 1,753 & - & 13,216 & 48,827 \\
\hline na.. & 13,565 & 9,288 & - & 22,853 & 1,245 & - & - & - & 1,245 & 24,098 \\
\hline is... & 12,025 & 20,261 & - & 32,286 & 162 & 4,385 & 2,168 & - & 6,715 & 39,001 \\
\hline an.. & 23,129 & 6,550 & - & 29,679 & 5 & - & - & - & 5 & 29,684 \\
\hline Wisconsin... & 8,211 & 5,764 & 141 & 14,116 & 2,334 & - & - & - & 2,334 & 16,450 \\
\hline Pest North Central & 49,989 & 20,361 & 6 & 70,356 & 143 & 1,759 & 一 & 一 & 1,902 & 72,258 \\
\hline Minnesota... & 12,373 & 6,186 & 一 & 18,559 & 25 & - & 一 & - & 25 & 18,584 \\
\hline Iowa........ & 7,150 & 6,695 & - & 13,845 & - & - & 一 & - & - & 13,845 \\
\hline uri... & 12,045 & - & - & 12,045 & 79 & - & - & - & 79 & 12,124 \\
\hline Dak & 1,840 & 760 & - & 2,600 & 26 & - & - & 一 & 26 & 2,626 \\
\hline So & 3,434 & 491 & 6 & 3,931 & 13 & - & - & - & 13 & 3,944 \\
\hline Nebraska. & 5,903 & 3,772 & - & 9,675 & - & 1,759 & - & - & 1,759 & 11,434 \\
\hline n938, & 7,244 & 2,457 & - & 9,701 & - & - & - & - & 一 & 9,701 \\
\hline antic.. & $|102,292|$ & 12,995 & - & 115,287 & 6,820 & - & 5,470 & 177 & 12,467 & 127,754 \\
\hline are.... & 2,122 & & - & 2,123 & - & - & - & 13 & 13 & 2,136 \\
\hline ind. & 6,382 & 4,220 & - & 10,602 & - & - & - & - & - & 10,602 \\
\hline$t$ of Colun & - & 2,789 & - & 2,789 & & 一 & - & 一 & 7 & 2,796 \\
\hline $\mathrm{V}$ & 17,221 & 377 & - & 17,598 & - & - & - & 13 & 13 & 17,611 \\
\hline b & 10,394 & 一 & - & 10,394 & - & - & - & - & - & 10,394 \\
\hline $\mathrm{N}$ & 24,430 & - & - & 24,430 & 915 & - & - & 113 & 1,028 & 25,458 \\
\hline are & 10,043 & 2,223 & 一 & 12,265 & 176 & - & - & - & 176 & 12,442 \\
\hline & 9,947 & 3,385 & 一 & 13,332 & 3,665 & - & 3,733 & - & 7,398 & 20,730 \\
\hline a... & 21,753 & - & - & 21,753 & 2,057 & - & 1,737 & & 3,832 & 25,585 \\
\hline East South Centra & 35,629 & 18,915 & 516 & 55,060 & 1,034 & - & - & 1,840 & 2,874 & 57,934 \\
\hline cky.. & 12,107 & 1,684 & - & 13,791 & - & - & - & - & - & 13,791 \\
\hline & 10,359 & 5,389 & 22 & 15,770 & 1,034 & - & - & 1,840 & 2,874 & 18,644 \\
\hline & 7,173 & 7,129 & - & 14,302 & - & - & - & - & - & 14,302 \\
\hline opi. & 5,990 & 4,713 & 494 & 11,197 & - & - & - & - & 一 & 11,197 \\
\hline Ceniral. & 61,407 & 6,542 & - & 67,949 & 2,873 & 2,760 & 12,427 & 1,330 & 19,390 & 87,339 \\
\hline & 9,086 & 1,309 & - & 10,395 & - & - & - & - & - & 10,395 \\
\hline L & 10,696 & - & - & 10,696 & 2,723 & 2,760 & 1,331 & 1,330 & 8,144 & 18,840 \\
\hline oma & 9,913 & 3,593 & - & 13,506 & 150 & - & - & - & 150 & 13,656 \\
\hline $\mathbf{T}$ & 31,712 & 1,640 & - & 33,352 & - & - & 11,096 & - & 11,096 & 44,448 \\
\hline lout & 27,706 & 5,294 & - & 33,000 & - & 一 & - & & & 33,002 \\
\hline$M$ & 4,674 & - & $\longrightarrow$ & 4,674 & - & 一 & 一 & - & - & 4,674 \\
\hline Is & 3,108 & 1,200 & - & 4,308 & - & - & 一 & - & - & 4,308 \\
\hline ming.. & 1,908 & 661 & - & 2,569 & - & - & - & - & - & 2,569 \\
\hline and & 5,586 & 2,076 & - & 7,662 & - & - & - & - & - & 7,662 \\
\hline $\mathrm{N}$ & 4,272 & - & - & 4,272 & - & 一 & - & - & - & 4,272 \\
\hline A & 3,105 & 1,357 & - & 4,462 & - & - & - & 2 & & 4,464 \\
\hline Utah... & 3,721 & - & - & 3,721 & - & - & - & - & - & 3,721 \\
\hline & 1,332 & - & - & 1,332 & - & - & - & - & - & 1,332 \\
\hline$a c i j$ & 44,020 & 26,926 & 8 & 71,032 & - & 3,906 & - & - & 3,906 & 74,938 \\
\hline ington. & 6,889 & 8,068 & - & 14,957 & - & 999 & - & - & 999 & 15,956 \\
\hline Oregon... & 8,467 & 1,718 & 86 & 10,271 & - & - & - & $\longrightarrow$ & - & 10,271 \\
\hline California....... & 28,664 & 17,140 & - & 45,804 & - & 2,907 & - & - & 2,907 & 48,711 \\
\hline
\end{tabular}

*Includes debt service charges on emergency relief bond issues, prorated in proportion to use of proceeds for state highways, local roads and streets, and non-highway purposes.

foriginally appropriated for relief but later transferred by legislative action to the state general fund.

A Appropriations for highway purposes out of the state general fund have been credited against payments of motor-fuel tax and motor-vehicle revenues to the general fund and prorated in proportion to net receipts from highway user taxes not otherwise dedicated.

\$Expenditures for highway purposes have been credited against payments of motor-fuel tax and motor-vehicle revenues to the state general fund and prorated in proportion to net receipts from highway user taxes not otherwise dedicated.

Source: Federal Works Agency, Public Roads Administration, table issued September, 1940. 
money in the general funds of the state or local governments. Only seven states singled out the motorist to help support relief. The same number of states called upon the purchaser of motor fuel to do his bit to keep our school fires burning.

The diversion of gasoline tax revenues is almost negligible in ten of the states, including the District of Columbia which follows the practice. These are, besides the District, Arizona, Delaware, Michigan, Minnesota, Missouri, North Dakota, South Dakota, Vermont, and Virginia. In fact not one of these states diverts as much as one per cent. The extent of the practice among the twenty remaining states which follow it is indicated in the table which follows:

TABLE VI

States Using One Per Cent or More of Motor Fuel Tax Receipts for Non-Highway Purposes, 1939

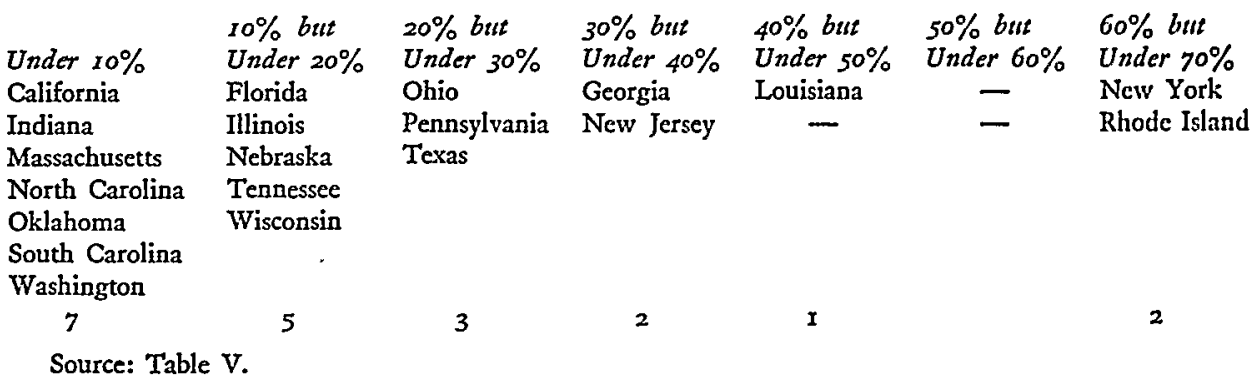

In view of the conditions under which motor fuel taxes were brought into existence, it is not surprising that any attempt to use the revenues from this source for non-highway purposes would be resisted. As diversion increased attempts were made to prevent it by one means or another. Several states have gone so far as to amend their constitutions in this respect. These states, with dates of ratification, are: California (1938), Colorado (I934), Idaho (1940), Kansas (1928), Michigan (1938), Minnesota (1928, motor fuel revenue, and 1932 , motor vehicle license revenue), Missouri (r928), Nevada (1940), New Hampshire (1938), North Dakota (1940) and South Dakota (1940). In I939, "Iowa passed a legislative resolution prohibiting the diversion of gas and motor fees from road uses. Anti-diversion constitutional amendments were proposed without success in Kentucky, New Jersey, Rhode Island, and Virginia." Such rejection by the voters of proposals for amending state constitutions is in the right direction since earmarking and diversion should be subjects left for the consideration of the state legislature.

In the absence of specific constitutional prohibition against diversion, recourse has been had to all manner of express or implied constitutional provisions in an effort to achieve the same result. Ready-made for the occasion, seemingly, was the doctrine that one group cannot be taxed for the benefit of another. This doctrine, the basis for which becomes clearer the narrower the tax base and the more distinct the group

- Letter from C. A. Curtis, Acting Commissioner of Public Roads, March 3T, $294 \mathrm{x}$.

${ }^{7} 4$ The Book of the STATES, I94I-1942 (194I) ro8. 
to be aided by the expenditure of the tax monies, is sometimes conceived of as a form or special phase of the more familiar public purpose rule, ${ }^{8}$ at other times as an application of the equal protection principle ${ }^{9}$ or an offshoot of due process independent of the public purpose concept. ${ }^{10}$ But despite the appropriateness of such a constitutional doctrine to establishment of a bar to diversion of tax monies, it has seldom been advanced by counsel in litigating gasoline-tax, or indeed any other form of consumption-tax diversion. ${ }^{11}$ The explanation probably lies in the fact that courts are chary of a doctrine which if consistently applied would throw into chaos the tax systems of the states and Federal Government. Although United States v. Butler ${ }^{12}$ is difficult to comprehend unless the Court there intended to apply this limitation to federal taxing and spending powers, ${ }^{13}$ neither before ${ }^{14}$ nor since $^{15}$ the time of that decision has success crowned efforts of counsel to secure the Court's judicial disapproval of state action on the ground that it imposes on a particular class a fiscal burden beneficially common to others as well. State reports, however, are not devoid of tangible evidence of successful resort to this doctrine. ${ }^{16}$

While gasoline tax funds are not likely to be judicially recognized, because of their source, as earmarked for highway purposes, some success has attended the challenge of diversion on other grounds. If the purpose for which the revenues are diverted can be labeled as "private," as was successfully done in In re Opinion of the

\footnotetext{
${ }^{8}$ See, e.g., I Cooley, Taxation (4th ed. 1924) 650; Haines, Judicial Revieu of the Acts of Congress and the Need for Constitutional Reform (1936) 45 YALE L. J. 816, 829. The latter reference speaks of the doctrine as being "a new form of the public purpose principle" read into constitutional law by United States v. Butler, 297 U. S. I (I935). In this it is in error because the principle can be traced back about as far as can that of public purpose.
}

${ }^{\circ}$ Note (1936) 45 YALE L. J. 729, 730; Lowry v. City of Clarksdale, 154 Miss. 755, x22 So. I95 (1929). Or of the analogous but more strict uniformity principle of somẹ state constitutions. Gilman v. City of Sheboygan, 2 Bl. 5 ro (U. S. 1862 ).

${ }^{10}$ See Kelly v. Pittsburgh, ro4 U. S. 78 (x88x); State v. Lafayette Fire Ins. Co., $x_{34}$ La. 78,63 So. 630 (1913) (fundamental principle of taxation by free governments).

The limitation is usually keyed to the due process clause where the claim is, as in Kelly $\nu$. Pittsburgh and State $v$. Lafayette Fire Ins. Co., both supra, that those taxed can derive no benefit whatever from the exaction, all benefit going to others; to the equal protection clause where, as in the Lowry case, supra note 9 , the tax group claims that the exaction is disproportionate to the benefit, which others equally enjoy.

${ }^{11}$ Search indicates that the issue was raised in In re Opinion of the Justices, 59 S. D. 469,240 N. W. 600 (1932) (motor vehicle fuel taxes-feed and loans to distressed live stock raisers); Stults Eagle Drug Co. v. Luke, 48 Ariz. 467,62 P. (2d) II26 (1936) (luxury taxes on cosmetics, playing cards, tobacco products, etc.-unemployment relief). In both cases the contention was unavailing.

${ }^{13}$ Supra note 8.

${ }^{13}$ Sce Grant, Commerce, Production, and the Fiscal Powers of Congress (r936) 45 YALE L. J. 75I, $766-768$, and $99 \mathrm{r}$, roog-roro.

is County of Mobile v. Kimball, I02 U. S. 69r (1880), where the financial burden of improving Mobile harbor, of distinct commercial value to the entire State of Alabama, was placed upon the County of Mobile.

${ }^{16}$ New York Rapid Transit Corp. v. City of New York, 303 U. S. 573, 584-587 (1938), where New York City's unemployment relief burden was cast upon local utilities.

${ }^{10}$ See, e.g., Lowry v. City of Clarksdale, supra note 9; Continental Ins. Co. v. Smrha, r3x Neb. 791, 270 N. W. 122 (1936); City of Louisville v. Aetna Fire Ins. Co., 284 Ky. 154, r43 S. W. (2d) ro74 (1940), all invalidating as violative of the equal protection guaranty the imposition upon insurance companies of taxes for the support of firemen's pension funds. Contra in attitude is In re Hunter's Estate, 97 Colo. 279, 49 P. (2d) 1009 (1935), two judges dissenting, sustaining additional motor vehicle registration, inheritance and incorporation fees for the financing of unemployment relief. 
Tustices, ${ }^{17}$ the issue has been held within justiciable limits which the courts are willing to recognize by virtue of the established character of the principle that taxes must be for a public purpose..$^{18}$ Use of such funds for relief purposes was stopped in Smithberger v. Banning ${ }^{19}$ on the ground that the appropriation carried an unconstitutional delegation of legislative powers. Invoked also, but without success, have been the express state constitutional provisions fixing maximum debt limits, ${ }^{20}$ forbidding impairment of the obligation of contract, ${ }^{21}$ and voiding tax legislation which embraces more than one subject or one not expressed in the title. ${ }^{22}$ Other litigation, however, indicates a fair amount of judicial receptiveness to challenges of gasoline tax diversion that are couched in terms of the common constitutional clause requiring that every taxing act distinctly state the object of the levy and expressly or inferentially prohibiting use of the monies for any other purpose. Not only will such a clause checkmate diversion of funds at hand and appropriated; ${ }^{23}$ recent South Carolina decisions limit the assumed power ${ }^{24}$ of succeeding legislatures to establish new uses for the money raised. The South Carolina court takes the position ${ }^{25}$ that inasmuch as the object stated in the state's gasoline tax levies is furtherance of a highway program, it does not suffice for the legislature merely to redirect the funds derived therefrom without altering the basic purpose therein expressed. ${ }^{26}$

Nationally, resistance to diversion has taken the form of a Congressional enactment of 1934, the Hayden-Cartwright Act, the pronounced effect of which on stabilization of the diversion upswing has already been noted. The pertinent section of this statute is worth quoting: $:^{27}$

Since it is unfair and unjust to tax motor vehicle transportation unless the proceeds of such taxation are applied to the construction, improvement, or maintenance of highways, after June 30, I935, Federal aid for highway construction shall be extended only to those states that use at least the amounts now provided by law for such purposes in each state from state motor vehicle registration fees, licenses, gasoline taxes, and other special taxes on motor vehicle owners and operators of all kinds for the construction, improvement,

\footnotetext{
${ }^{17}$ Supra note II.

${ }^{18}$ See the discussion in Note (1936) 45 YaIE L. J. 729, 730.

${ }^{19} 129$ Neb. 651, 262 N. W. 492 (1935).

${ }^{20}$ State $e x$ rel. v. Martin, 173 Wash. 249, 23 P. (2d) I (1936) (diversion for unemployment relief).

${ }^{21}$ Michaels v. Barrett, 355 Ill. 175, I88 N. E. 921 (1934) (same).

${ }^{22}$ Ibid.

${ }^{23}$ White Eagle Oil Co. v. Gunderson, 48 S. D. 608,205 N. W. 614 (1925) (diversion for state enterprise); In re Opinion of the Justices, stipra note II.

${ }^{24}$ See Michaels v. Barrett, supra note 21.

${ }^{25}$ State $e x$ rel. v. Osborne, I93 S. C. 158 , 7 S. E. (2d) 526 (1940), id. 195 S. C. 295, 11 S. E. (2d) 260 ( 1940 ) (diversion for general state expenses).

${ }^{20}$ Buttressing this view in the court's mind was the less usual South Carolina constitutional provision which specifies that the legislature shall provide for state expenses and deficits-the object for which diversion was here attempted-by the levy of a special tax and not by mere appropriation of monies derived from prior taxation.

${ }_{2 \pi} 48$ STAT. 995,23 U. S. C. $\$ 55$ (1934). Additional encouragement, over and above the HaydenCartwright Act, of limitation of the non-highway use of motor fuel tax collections is given by another section of the Federal Highway Act which provides that under certain conditions the matching requirements for federal aid are suspended. One of the conditions is that all taxes on motor vehicle uransportation be used for highway purposes. 52 STat. 633, S1C (1938), 54 Stat. - (1940), 23 U. S. C. A. \$10(b)
} (1940). 
and maintenance of highways and administrative expenses in connection therewith, including the retirement of bonds for the payment of which such revenues have been pledged, and for no other purposes, under such regulations as the Secretary of Agriculture shall promulgate from time to time: Provided, that in no case shall the provisions of this section operate to deprive any state of more than one-third of the amount to which that state would be entitled under any apportionment hereafter made, for the fiscal year for which the apportionment is made.

Three states have been penalized under the provisions of this section of the act. In 1937 New Jersey/ was deprived of $\$ 250,000$ of federal aid funds and a year later (I938) Massachusetts had $\$ 472,862$ of such funds denied her. In I940 a penalty of $\$ 504,074$ was placed on Georgia. ${ }^{28}$ It is extremely difficult to justify federal enactment of such a penalty for the diversion of state gasoline tax monies. Federal aid should be granted outright or on the basis of matching with state funds, or withdrawn altogether. One cannot but agree with the Tax Policy League that "this seems the most unwarranted bit of interference with state finances upon the part of Congress that has been exhibited by that body."29

\section{Conclusion}

In conclusion it must be said that the great variety of methods now in use in distributing the revenues from consumer taxes indicates there is no single, simple formula which will meet all situations. No doubt the method adopted has often been more the result of political expediency and local condition than of sound theory. Perhaps the latter does not now exist; certainly the question of allocation merits serious and continued investigation. Undoubtedly the earmarking of receipts from certain tax sources for specific purposes can be justified, but its proponents are very likely to overstep the bounds and to forget that its use should be very severely restricted. Benefit should be the guide. This should not preclude, for example, subjecting retail sales of gasoline to the sales tax, and using the revenues therefrom for general purposes although gasoline may be already taxed for the support of highways. Once the yield from a tax is earmarked it should not be diverted. There seems to be little tendency for diversion to increase relatively, although the actual amount in dollars and cents may show either increases or decreases depending upon economic conditions.

${ }^{28}$ Letter from C. A. Curtis, Acting Commissioner of Public Roads, March. 3I, I94T.

so (April, I938) 5 TAX PoLscy No. 5. See also Magill, Trends in Public Finance (1940) I8 Taxes 3, 6; Crawford, The Gasoline Tax-Its Use and Abuse (I940) I8 id. 83, 84-85. 